\title{
At-Turats
}

Jurnal Pemikiran Pendidikan Islam

journal homepage: http://jurnaliainpontianak.or.id/index.php/atturats

\section{MANAJEMEN MUTU KURIKULUM DAN PEMBELAJARAN BAHASA ARAB}

\author{
Moh Yusuf Hidayat \\ Fakultas Tarbiyah dan Ilmu Keguruan (FTIK) \\ Institut Agama Islam Negeri (IAIN) Pontianak
}

\begin{abstract}
A B S T R A K
Dalam rangka pelaksanaan konsep manajemen ini, strategi yang dapat dilaksanakan oleh pemangku kebijakan antara lain meliputi evaluasi diri untuk menganalisa kekuatan dan kelemahan kurikulum. Berdasarkan hasil evaluasi tersebut sekolah bersama-sama orang tua dan masyarakat menentukan visi dan misi kurikulum dalam peningkatan mutu pendidikan Manajemen alternatif ini memberikan kemandirian kepada peletak dasar, pengembang dan pelaksana kurikulum sekolah untuk mengatur dirinya sendiri dalam rangka peningkatan mutu pendidikan, tetapi masih tetap mengacu kepada kebijakan nasional. Setidaknya ada tiga hal yang harus diperhatikan dalam kegiatan ini yaitu; pertama, pengembangan kurikulum tersebut harus memenuhi kebutuhan siswa. Kedua, bagaimana mengembangkan keterampi-lan pengelolaan untuk menyajikan kurikulum tersebut kepada siswa sedapat mungkin secara efektif dan efisien dengan memperhatikan sumber daya yang ada. Ketiga, pengembangan berbagai pendekatan yang mampu mengatur perubahan sebagai fenomena alamiah di sekolah.
\end{abstract}

Kata kunci : kurikulum, manajemen, mutu, pendidikan, dan sekolah

\section{PENDAHULUAN}

Perkembangan ilmu pengetahuan dan teknologi telah membawa perubahan di hampir semua aspek kehidupan manusia dimana berbagai permasalahan hanya dapat dipecahkan kecuali dengan upaya penguasaan dan peningkatan ilmu pengetahuan dan teknologi. Selain manfaat bagi kehidupan manusia di satu sisi perubahan tersebut juga telah membawa manusia ke dalam era persaingan global yang semakin ketat. Agar mampu berperan dalam persaingan global, maka sebagai bangsa kita perlu terus mengembangkan dan meningkatkan kualitas sumber daya manusianya. Oleh karena itu, peningkatan kualitas sumber daya manusia merupakan

\footnotetext{
${ }^{1}$ A. Hanief Saha Ghafur, Manajemen Penjaminan Mutu Perguruan Tinggi di Indonesia, ( Jakarta, Bumi Aksara, 2008) hal. 1
}

kenyataan yang harus dilakukan secara terencana, terarah, intensif, efektif dan efisien dalam proses pembangunan, kalau tidak ingin bangsa ini kalah bersaing dalam menjalani era globalisasi tersebut.

Berbicara mengenai kualitas sumber daya manusia, pendidikan memegang peran yang sangat penting dalam proses peningkatan kualitas sumber daya manusia. Indonesia, sebagai negara berkembang, terus berupaya untuk memberikan perhatian dalam rangka memajukan kesejahteraan umum dan mencerdaskan kehidupan bangsa melalui pendidikan. ${ }^{1}$ Peningkatan kualitas pendidikan merupakan suatu proses yang terintegrasi dengan proses peningkatan kualitas sumber daya manusia itu sendiri. Menyadari pentingnya proses peningkatan 
kualitas sumber daya manusia, maka pemerintah bersama kalangan swasta samasama telah dan terus berupaya mewujudkan amanat tersebut melalui berbagai usaha pembangunan pendidikan yang lebih berkualitas antara lain melalui perbaikan sarana pendidikan, pengembangan dan pengadaan materi ajar, pelatihan bagi guru dan tenaga kependidikan lainnya serta pengembangan dan perbaikan mutu kurikulum dan sistem evaluasi. Perbaikan mutu kurikulum lebih kepada upaya memperbaiki mutu kurikulum dan aspekaspek pembelajaran yang menjadi bagian yang tidak terpisahkan. Fokus perbaikan mutu kurikulum berangkat dari upaya perbaikan manajemen mutu kurikulum dan aspek pembelajaran. Aspek pembelajaran yang dimaksud dalam makalah ini adalah lebih fokus pada pembelajaran bahasa Arab.

\section{KONSEP MANAJEMEN}

Manajemen mengandung arti sebagai sebuah proses khas, yang terdiri dari tindakan-tindakan; perencanaan, pengorganisasian, penggiatan dan juga pengawasan $^{2}$. Ini semua juga dilakukan untuk menentukan atau mencapai sasaransasaran yang telah ditetapkan melalui pemanfaatan sumber daya manusia dan juga sumber-sumber lainnya. Manajemen pada dasarnya merupakan suatu proses penggunaan sumber daya secara efektif untuk mencapai sasaran atau tujuan tertentu. ${ }^{3}$ Manajemen dalam perspektif ekonomi berorientasi profit (keuntungan) dan komoditas komersial.

Dari pengertian tersebut tersebut dapat diketahui bahwa manajemen adalah applied science (ilmu aplikatif), dimana jika dijabarkan menjadi sebuah proses tindakan meliputi beberapa hal :

\footnotetext{
${ }^{2}$ A. Halim, dkk. Manajemen Pesantren, (Yogyakarta, Pustaka Pesantren,2009) hal. 71.

${ }^{3}$ Muhaimin, dkk. Manajemen Pendidikan aplikasinya dalam penyusunan rencana pengembangan sekolah/madrasah, ( Jakarta, Kencana , 2011) hal. 4
}

a. Perencanaan (planning)
Fungsi perencanaan mencakup penetapan tujuan, standar, penentuan aturan-prosedur dan pembuatan rencana serta ramalan (prediksi) apa yang diperkirakan terjadi. Plan merupakan kegiatan yang bertujuan untuk memantapkan tujuan dan proses yang dibutuhkan untuk mencapai hasil yang sesuai dengan persyaratan pelanggan dan kebijakan organisasi. ${ }^{4}$

\section{b. Pengorganisasian (organizing)}

Fungsi pengorganisasian ini meliputi: pemberian tugas yang terpisah kepada masing-masing pihak, membentuk bagian, mendelegasikan, atau menetapkan jalur wewenang/tanggung jawab ${ }^{5}$ dan sistem komunikasi, serta mengkoordinir kerja setiap bawahan dalam suatu tim kerja yang solid dan terorganisir.

\section{c. Penggerakan (Actuating)}

Setelah kegiatan perencanaan/ pengorganisasian, pimpinan perlu menggerakkan kelompok secara efisien dan efektif ke arah pencapaian tujuan. Dalam menggerakkan kelompok ini pimpinan menggunakan pelbagai sarana meliputi: komunikasi, kepemimpinan, perundinganperundingan, pemberian instruksi dan lainlain. Dengan actuating ini, pimpinan berusaha menjadikan organisasi bergerak dan berjalan secara aktif dan dinamis.

\section{d. Pengawasan (Controlling)}

Fungsi ini juga bisa disebut dengan pengendalian atau evaluasi. Ketika organisasi telah bergerak dan berjalan, pimpinan harus selalu mengadakan pengawasan atau pengendalian agar gerakan atau jalannya organisasi benarbenar sesuai dengan rencana yang telah

\footnotetext{
${ }^{4}$ Listyo prabowo, Sugeng. Implementasi Sistem Manajemen Mutu ISO 9001 : 2008 di Perguruan Tinggi (Guidelines IWA-2), (Malang, UIN-Malang Press) hal. 56.

${ }^{5}$ A. Halim, op. cit. hal 71
} 
ditetapkan, baik mengenai arahnya maupun caranya. Controlling merupakan tahapan proses monitoring dan evaluasi terhadap proses dan produk yang tidak sesuai dengan kebijakan, tujuan dan persyaratan produk serta melaporkan hasilnya. ${ }^{6}$

Adapun proses manajemen dapat digambarkan dalam gambar berikut ini :

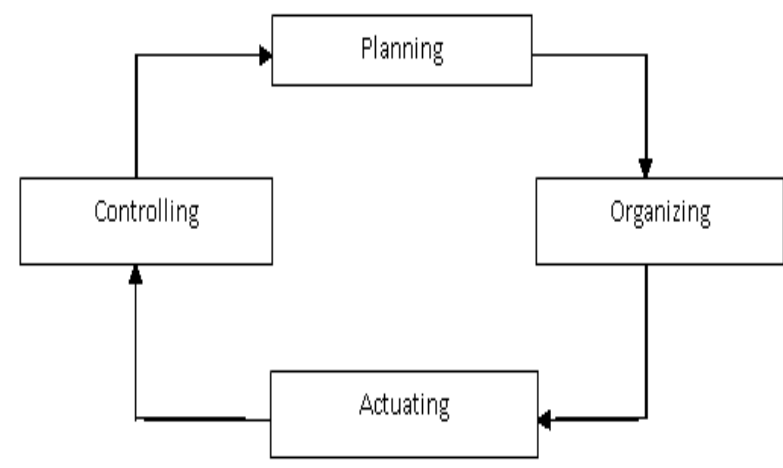

Manajemen dibutuhkan dalam semua hal. Seperti yang telah diutarakan di awal bahwa inti manajemen lebih berkisar pada aspek perencanaan, pengorganisasian, pelaksanaan dan monitoring. ${ }^{7}$ Manajemen mutu kurikulum - sebagai upaya menjaga akuntabilitas pendidikan terhadap hak-hak masyarakat - sangat penting dalam rangka menjamin kepercayaan stakeholder terhadap upaya pemangku pendidikan dalam memajukan kualitas mutu kurikulum sebagai aspek penting dalam dunia pendidikan. Kualitas mutu kurikulum akan sangat ditentukan oleh pola manajemen kurikulum itu sendiri. Pola manajemen yang dimaksud adalah pola yang berlandaskan pada input-proses-output. Istilah mutu sendiri memiliki pengertian yang bertentangan. Pleffer dan Coote menyebut definisi mutu sebagai konsep yang licik ( a slippery concept $)^{8}$.

Hal ini disebabkan istilah bermutu berkaitan dengan sudut pandang dan sudut

\footnotetext{
${ }^{6}$ Listyo prabowo, Sugeng. Implementasi Sistem Manajemen Mutu ISO 9001 : 2008 di Perguruan Tinggi (Guidelines IWA-2), (Malang, UIN-Malang Press) hal. 57.

${ }^{7}$ Jamal Ma'mur Asmani, Manajemen Strategis Pendidikan Anak Usia Dini, ( Yogyakarta, Diva Press,2009) hal. 87.
}

kepentingan pengguna istilah yang berbedabeda. Perbedaan terjadi disebabkan oleh konsep mutu yang bertolak dari standar absolut (absolut concept) dan standar yang relatif (relative concept). Standar absolut beranggapan bahwa mutu merupakan suatu keindahan, kebenaran yang pasti dan tanpa kompromi. ${ }^{9}$ Sementara yang relatif bertolak dari pikiran mutu merupakan sesuatu yang not be expensive dan exclusive...may be beautiful but not necessarily so. ${ }^{10}$ They do not have to be special. They can be ordinary, commonplace and familiar. Alasan definisi relatif berdasarkan pada kenyataan adanya perbedaan antara kepentingan subyek penghasil barang atau jasa dengan kepentingan pemakai barang atau jasa. Namun justru dalam hal ini keanehannya saat subyek penghasil berorientasi pada kepentingan pemakai, para pemakai sendiri lebih berorientasi pada persepsinya.

Dalam dunia pendidikan, dua pertanyaan pokok yang penting dikemukakan adalah apa hasil pendidikan dan siapa pemakai hasil pendidikan tersebut ? Hasil pendidikan berupa nilai tambah bagi subyek didik, memiliki tingkat kepentingan yang berbeda antara subyek didik itu sendiri sebagai pemakai utama hasil didikan, dengan orang tua sebagai pemakai kedua, pasar tenaga kerja sebagai pemakai ketiga dan guru atau staf pendukung sebagai orang yang terlibat dalam proses pendidikan yang justru "menggunakan" subyek didik itu sendiri.

Dalam pada itu secara substantif istilah mutu sendiri mengandung dua hal. Pertama sifat dan kedua taraf. Sifat adalah sesuatu yang menerangkan keadaan benda sedang taraf menunjukkan kedudukannya dalam suatu skala. Tiap manusia memiliki

\footnotetext{
${ }^{8}$ Lihat juga pada definisi yang dikemukakan Edward dan Sallis (1993) hal. 21

${ }^{9}$ Sanusi Uwes, Manajemen Pengembangan Mutu Dosen, ( Ciputat, Logos Wacana Ilmu, 2003) hal.26. ${ }^{10}$ Ibid.
} 
pandangan yang berbeda tentang sifat dan taraf tersebut. Demikian juga halnya terhadap sifat dan taraf mutu pendidikan serta lebih-lebih pada sifat dan taraf mutu kurikulum. Pada akhirnya terdapat deskripsi tentang sifat dan taraf yang berbeda. Deskripsi yang dimaksud lebih kepada pendekatan ekonomi dengan penekanan pada relevansi keluaran pendidikan dengan lapangan kerja yang ditampilkan melalui istilah-istilah "siap pakai" "siap kerja" dan "siap latih" akan berbeda dengan deskripsi yang memakai pendekatan intrinsik dan instrumental pendidikan. Pendekatan kedua ditampilkan melalui istilah-istilah sikap, kepribadian dan kemampuan intelektual sesuai dengan tuntutan tujuan pendidikan nasional.

\section{KONSEP MUTU}

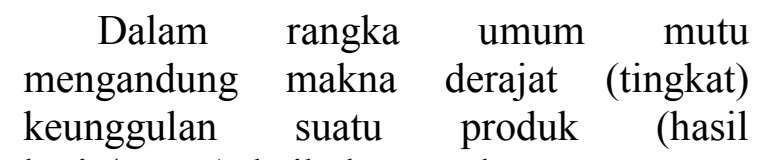
kerja/upaya) baik berupa barang maupun jasa; baik yang tangible maupun yang intangible. Dalam konteks kurikulum pengertian mutu, dalam hal ini mengacu pada pertama proses rancangan dan hasil kurikulum. Dalam "proses rancangan kurikulum" yang bermutu terlibat berbagai input, seperti; kerapian, kecerdasan, dan akurat sehingga melahirkan relasi erat antara mata pelajaran satu dengan yang lainnya. Kedua kurikulum harus bersifat fleksibel dan bersifat konstektual ${ }^{11}$ dengan kepentingan-kepentingan pendidikan tertentu. Dengan kata lain, bisa diubah metode ataupun muatannya selama tidak menyimpang dari tujuan dan kepentingan bersama yang sudah disepakati. Ketiga kurikulum hendaknya dususun bersama oleh para guru dan sejumlah elemen lain yang mengutamakan kepentingan bersama demi tujuan pendidikan di tingkat daerah

\footnotetext{
${ }^{11}$ Moh Yamin. Panduan Manajemen Mutu Kurikulum Pendidikan, (Yogyakarta, Diva Press, 2012) hal. 19
}

dan tetap berdasarkan kepada tujuan pendidikan nasional. Dengan demikian terjalin sinergi dan harmonisasi antara tujuan kepentingan lokal dan nasional. Keempat kurikulum hendaknya mencakup segala pengalaman anak di bawah pimpinan sekolah.

Dalam pandangan modern, kurikulum tidak hanya mengulas mata pelajaran yang diberikan dalam kelas namun juga meliputi segala kegiatan yang mengandung unsur pendidikan. Kelima kurikulum hendaknya berpusat pada persoalan sosial dan pribadi yang bermakna bagi anak dalam kehidupan sehari-hari. Keenam kurikulum harus diselenggarakan sebagai sarana mencapai cita-cita nasional yang berlandaskan filsafat negara.

Sekolah harus bertanggung jawab dalam pembentukan masyarakat Indonesia yang bersatu dan sanggup menempatkan kepentingan negara di atas kepentingan pribadi dan golongan. Ketujuh kurikulum harus memberikan pengalaman yang luas dan bermakna kepada anak-anak dan tidak bersifat tekstual. Kedelapan kurikulum harus diatur dengan sedemikian rupa sehingga anak-anak bisa mempelajari teknik belajar, cara kerja efektif dan memecahkan masalah. Kesembilan kurikulum hendaknya membuka kesempatan kepada setiap anak untuk mengembangkan minat dan bakatnya masingmasing.

Mutu dalam konteks "hasil kurikulum" mengacu pada efisien dan efektifnya kurikulum dalam menjalankan fungsi pendidikan, ${ }^{12}$ lantas apakah peran penting yang dipegang oleh kurikulum sehingga strategis dalam pembangunan pendidikan yang berkualitas ? sebagai jawabannya adalah bahwa kurikulum secara hakiki adalah jalan yang harus ditempuh peserta didik guna mencapai tujuan program pendidikan. Tanpa adanya kuri-kulum yang

\footnotetext{
${ }^{12}$ Moh Yamin. Panduan Manajemen Mutu Kurikulum Pendidikan, (Yogyakarta, Diva Press, 2012) hal. 36
} 
jelas maka tujuan pendidikan yang akan dicapai akan menjadi kabur. Bila tidak disebut demikian maka tujuan pendidikan yang dihasilkan pun tidak akan sesuai dengan target yang akan diraih. Oleh sebab itu, kurikulum merupakan penunjuk arah ke mana pendidikan akan dituntun dan diarahkan atau akan menghasilkan output pendidikan.

\section{KONSEP KURIKULUM}

Dilihat dari sisi sejarah, istilah kurikulum adalah suatu istilah yang berasal dari bahasa Yunani. ${ }^{13}$ Perkataan kurikulum dikenal sebagai suatu istilah dalam dunia pendidikan sejak kurang lebih satu abad yang lampau. A race course; a place for running; a chariot dan a course in general; applied particulary to the course of studi in a university adalah arti kurikulum pada waktu itu. ${ }^{14}$ Adapun di Indonesia istilah kurikulum baru menjadi populer sejak tahun lima puluhan dan kelaziman arti rencana pelajaran adalah muncul seiring pemaknaan kurikulum pada waktu itu yang diartikan sebagai sesuatu yang direncanakan untuk pelajaran anak. Dalam teori dan praktik pengertian kurikulum lama sudah banyak ditinggalkan, hal ini dikarenakan bahwa dalam perkembangan selanjutnya para ahli pendidikan memberi arti da isi yang lebih luas dari pada semula.

Agus Suwignyo ${ }^{15}$ menyatakan bahwa kurikulum tetap menjadi perangkat yang umum diketahui strategis untuk menyamai kepentingan dan membentuk konsepsi dan prilaku individu. A. Ferry T. Indratno menambahkan bahwa kurikulum adalah program dan isi dari suatu sistem pendidikan yang berupaya melaksanakan proses akumulasi pengetahuan antar generasi

\footnotetext{
${ }^{13}$ S. Nasution, Asas-asas Kurikulum, (Jakarta : PT Bumi Aksara, 2006) hal.

${ }^{14}$ Ibid. hal 1

${ }^{15}$ Agus Suwignyo, Kurikulum dan Politik (kebijakan) Pendidikan dalam Kurikulum yang mencerdaskan, Visi 2030 dan Pendidikan alternatif (Jakarta : Kompas, 2007) hal. 38
}

dalam masyarakat. ${ }^{16}$ Dari dua definisi diatas ditarik sebuah benang merah bahwa kurikulum dipahami sebagai alat sentral bagi keberhasilan pendidikan. Peran ini menjadi kunci bagaimana pendidikan akan diarahkan. Ini berkaitan erat dengan proses pembelajaran sebagai ruang beraktivitas belajar anak didik supaya mereka mendapat bekal pengetahuan yang baik dan mampu membangun kekuatan kecerdasan baik kognitif, afektif dan psikomotorik.

Karakteristik kurikulum yang ada dan berkembang akhir-akhir ini tidak lebih dari suatu proses daripada pemberian pengertian individu yang dilakukan secara terus menerus ke arah yang lebih berarti dan bermakna. Akibat dari interprestasi makna kurikulum sebagai running of the race ${ }^{17}$ maka definisi ini menekankan adanya kapasitas individu untuk berpartisipasi dan mengonsepkan kembali pengalaman hidup seseorang yang lebih berorientasi pada pegalaman pada sejatinya.

\section{KOMPONEN KURIKULUM}

Merujuk pada fungsi kurikulum sebagai alat mencapai tujuan pendidikan, maka sebagai alat pendidikan, kurikulum mempunyai komponen-komponen penunjang yang fungsinya saling mendukung antara satu dengan yang lain. Banyak para pakar pendidikan yang meletakkan ragam komponen kurikulum, meskipun pada akhirnya bertemu pada kesimpulan dan pengertian yang sama.

Pakar semisal Subandijah ${ }^{18}$ membagi komponen kurikulum ke dalam: (1) Tujuan, (2) Isi atau materi, (3) Organisasi atau strategi, (4) Media, (5) Komponen proses belajar mengajar. Adapun pembagian komponen kurikulum menurut Ralp W.

\footnotetext{
${ }^{16}$ Indratno, A. Ferry T. Kurikulum Beridentitas Kerakyatan dalam Kurikulum yang Mencerdaskan, Visi 2030 dan Pendidikan Alternatif (Jakarta : Kompas, 2007) hal. 108.

${ }^{17}$ Lihat definisi Pinar, Smith \& Lovat dalam Abdullah Idi, 2007. Hal 48.

${ }^{18}$ Lihat dalam Abdullah Idi, Pengembangan Kurikulum Teori dan Praktek, 2007.hal. 51.
} 
Tyler ${ }^{19}$ yakni (1) Tujuan, (2) Bahan pelajaran, (3) Proses belajar mengajar dan (4) Evaluasi dan penilaian. Keempat komponen saling berhubungan. Setiap komponen bertalian erat dengan ketiga komponen lainnya. Pada komponen tujuan menitikberatkan pada bahan apa yang akan dipelajari, karena hal ini berkaitan dengan sesuatu yang ingin dicapai secara keseluruhan yang meliputi domain kognitif, domain afektif dan domain psikomotorik. Domain kognitif adalah tujuan yang diingikan yang mengarah pada pengembangan ketrampilan jasmani anak didik.

Tujuan pendidikan nasional pun menghendaki pencapaian ketiga dominan yang ada secara integral dalam rangka memperoleh lulusan (output) pendidikan yang relevan dengan tujuan pendidikan nasional. Selanjutnya pada komponen isi atau materi yang menitikberatkan pada pemprograman yang bermuara pada pencapaian tujuan pendidikan yang telah ditetapkan ${ }^{20}$. Isi dan materi yang dimaksud biasanya berupa materi bidang-bidang studi misalnya bahasa arab dsb. Bidang-bidang studi tersebut disesuaikan dengan jenis, jenjang dan jalur pendidikan yang ada dan bidang-bidang studi tersebut biasanya telah dicantumkan atau dimuatkan dalam struktur program kurikulum suatu sekolah.

Kemudian pada komponen media yang menitikberatkan pada asumsi bahwa media adalah alat bantu untuk memudahkan dalam mengaplikasikan isi kurikulum agar lebih mudah dimengerti dalam proses belajar mengajar. Pemanfaatan media dalam proses belajar mengajar merupakan merupakan suatu hal yang perlu dilaksanakan oleh seorang pendidik atau guru agar apa yang disampaikannya terhadap anak didik dapat memiliki makna dan arti penting bagi anak didik. Terakhir pada komponen strategi

\footnotetext{
${ }^{19}$ Ada empat pertanyaan pokok berkaitan dengan komponen kurikulum yang diajukan oleh Ralp W. Tyler diantaranya Tujuan, memilih bahan pelajaran, bagaimana bahan disajikan dan kaitannya dengan efektifitas belajar.
}

belajar mengajar, pada komponen ini menekankan pentingnya pemahaman mendalam dari seorang pendidik tentang strategi. Strategi menunjuk pada suatu pendekatan (approach), metode (method), dan peralatan mengajar yang diperlukan dalam pengajaran.

\section{KONSEP PEMBELAJARAN BAHASA ARAB}

Menurut Zamroni pembelajaran diartikan secara umum adalah sebagai pendidikan yaitu suatu proses dam mengembangkan pada peserta didik pengetahuan tentang hidup, sikap dalam hidup agar kelak ia dapat membedakan barang yang benar dan yang salah, yang baik dan yang buruk, sehingga kehadirannya di tengah-tengah masyarakat akan bermakna dan berfungsi secara optimal. ${ }^{21}$ Pembelajaran menurut Sikun Pribadi guru besar IKIP Bandung menjelaskan bahwa pembelajaran adalah suatu kegiatan yang menyangkut pembinaan anak mengenai segi kognitif dan psikomotorik yaitu supaya anak-anak lebih banyak pengetahuannya, lebih cakap berfikir kritis, sistematis dan obyektif, serta terampil dalam mengerjakan sesuatu misalnya terampil menulis, membaca, laricepat, dan lain sebagainya ${ }^{22}$.

Ki Hajar Dewantara mengemukakan pendapatnya bahwa pembelajaran adalah pendidikan dengan cara memberikan ilmu pengetahuan serta kecakapan pada anak yang keduanya bisa bermanfaat bagi hidupnya baik lahir dan batin. Dari dua pengertian ini maka pembelajaran juga dapat diartikan adanya proses transformasi ilmu pengetahuan dari pendidik kepada peserta didik secara terus- menerus dan berulang-ulang serta membutuhkan keseriusan dalam berlatih melakukan

\footnotetext{
${ }^{20}$ Idi, Abdullah. Pengembangan Kurikulum Teori dan Praktek, (Yogyakarta, Ar ruzz Media, 2009) hal. 55

${ }^{21}$ Lihat Zamroni, 2001. hal 87

${ }^{22}$ Ahmad Tafsir, 2003. hal . 7.
} 
sesuatu hal agar dapat mengerti dan melakukan hal tersebut. Dari definisi tersebut dapat diketahui bahwa pembelajaran adalah merupakan usaha atau proses yang ditujukan untuk membina kualitas sumberdaya manusia seutuhnya agar ia dapat melakukan perannya dalam kehidupan secara fungsional dan optimal. Dan yang dimaksud pembelajaran dalam makalah ini adalah proses mengajarkan bahasa Arab sebagai muatan dan upaya alihtrasformasi bidang keilmuan bahasa arab kepada peserta didik yang berorientasi kepada kompetensi tertentu yang menjadi acuan keberhasilan di dalam pelaksanaan pembelajaran dan dalam rangka membina kualitas sumberdaya manusia dibidang pembelaran bahasa arab. Adapun proses pembelajaran yang dimaksud adalah 1.perencanaan pendidik bahasa Arab yang diwujudkan lewat persiapan sebelum mengajar dalam bentuk pembuatan rpp/sap dan silabus, 2. Pelaksanaan pembelaran itu sendiri yang dilakukan pendidik dalam ruang kelas, 3 . Proses pelaksanaan evaluasi yang dilakukan pendidik dalam rangka menilai keberhasilan pembelajaran dengan memberikan tes lisan dan tertulis kepada peserta didik.

\section{FUNGSI DAN TUJUAN PEMBELA-JARAN BAHASA ARAB}

Dalam tradisi intelektual keislaman bahasa Arab merupakan bagian terpenting, karenanya perlakuan khusus terhadap bahasa arab sebagai bahasa komunikasi atau pergumulan dalam mengkaji kajian keislaman tentu bukan sesuatu yang berlebihan, apalagi kontek institusi pendidikan formal maupun nonformal yang berafiliasai keislaman sudah semestinya menjadikan bahasa arab sebagai suatu mata

\footnotetext{
${ }^{23}$ Radliyah Zainuddin (dkk), Metodologi dan Strategi Alternatif Pembelajaran Bahasa Arab, (Yogyakarta, Pustaka Rihlah Group, 2005).
}

pelajaran atau mata rumpun dalam perkuliahan di lembaga pendidikan ${ }^{23}$.

Materi bahasa Arab merupakan materi yang berfungsi sebagai alat pengembangan diri peserta didik dalam bidang komunikasi, ilmu pengetahuan, teknologi, dan seni budaya. Dengan demikian mereka dapat tumbuh dan berkembang menjadi warga negara yang cerdas, terampil dan berkepribadian Indonesia serta siap mengambil bagian dalam pembangunan nasional. Nilai-nilai inilah yang melandasi pentingnya bahasa Arab sebagai bahasa komunikasi yang harus dikuasai oleh setiap penutur baik bangsa Arab sendiri atau non Arab.

Dengan demikian maka dapat dikatakan bahwa materi bahasa Arab sebagai kurikulum bagi jenjang pendidikan dasar menengah dan perguruan tinggi adalah a. melakukan penyesuaian, b. menghindari keterulangan, dan c. menjaga kesinambungan. Dengan tiga unsur tersebut maka diharapkan tampilnya dimensi pengetahuan, sikap, keterampilan, dan nilai pada masing-masing standar kompetensi yang telah dirumuskan baik antar kelas maupun antar jenjang.

Adapun program pembelajaran bahasa Arab secara umum memiliki tujuan agar para peserta didik berkembang ${ }^{24}$ dalam hal sebagai berikut:

1) Kemampuan mendengarkan, berbicara, membaca, dan menulis

2) Berbicara secara sederhana tapi efektif dalam berbagai konteks untuk menyampaikan informasi, pikiraan dan perasaan, serta menjalin hubungan sosial dalam bentuk kegiatan yang beragam, interaktif dan menyenangkan.

3) Menafsirkan isi berbagai bentuk teks tulis pendek sederhana dan merespon dalam bentuk kegiatan yang beragam, interaktif daan menyenangkan.

\footnotetext{
${ }^{24}$ Lampiran Peraturan Menteri Agama No. 2 Tahun 2008 tentang Standar Kompetensi Lulusan dan Standar isi Bahasa Arab
} 
4) Menulis kreatif meskipun pendek sederhana berbagai bentuk teks untuk menyampaikan informasi, mengungkapkan pikiraan dan perasaan.

5) Menghayati dan menghargai karya sastra.

6) Kemampuan untuk berdiskusi dan menganalisis teks secara kritis.

7) Perbendaharaan kata Arab fusha sebanyak 10000 kata dalam berbagai bentuk kata dan pola kalimat yang kegiatan ilmiah, diskusi, dan penulisan artikel kemahasiswaan.

\section{RUANG LINGKUP PELAJARAN BAHASA ARAB}

Aspek mata pelajaran bahasa Arab meliputi hal-hal sebagai berikut ${ }^{25}$ yaitu:

a. Keterampilan berbahasa, yaitu bercakap atau berbicara, menyimak, membaca, dan menulis. Bercakap adalah mengajarkan keterampilan menggunakan bahasa Arab secara lisan untuk mengembangkan kemampuan mengungkapkan berbagai fungsi komunikasi bahasa. Dengan menyimak peserta didik terlatih untuk memahami bahasa Arab lisan. Sedang membaca dapat mengajarkan peserta didik keterampilan membaca untuk mengembangkan kemampuan memahami isi wacana. Sementara menulis adalah untuk mengembangkan kemampuan menyusun kalimat-kalimat yang benar dalam karangan terpimpin (al Khitabah).

b. Unsur-unsur kebahasaan yang meliputi bentuk kata, kosa kata, struktur kalimat;

a. Bentuk Kata (Marfologi)

Unsur dalam bahasa yang melahirkan ilmu sharaf (Marfologi) dalam tingkatan perguruan tinggi terdiri dari tiga bentuk kata yaitu:

1. Isim, meliputi:
a) Isim dlamir ( munfashil, muttashil dan mustatar )
b) Isim Isyarah
c) Isim maushul

d) Isim Syart

e) Isim istifham

f) Zharfu

2. Fi'il, meliputi:

a) Madli, mudlari', dan

b) 'amar dengan berbagai tashrif nya

3. Huruf, meliputi:

a) Huruf-huruf jar

b) Huruf 'inna' wa akhawatiha

c) Harfu annida'

d) Harfu Istina'

e) Wawu al Ma'iyyah

f) Macam-macam lam (lam ta'lil, lam amar, lam taukid, dan lam nafi)

c. Kosa kata (fonologi)

Dalam mempelajari kosa kata (mufradat) inilah yang melahirkan ilmu funulujiyah (fonologi). Disamping fonologi yang memang selalu ada pada semua bahasa. Bahasa Arab memiliki ilmu-ilmu lain seperti rasam (grafologi), bayan (gaya bahasa), badi' (keindahan kata dan makna), 'arud (pola syair) qawafi (bunyi-bunyi/huruf-huruf pada fashila/akhir bait puisi), matnul lughah (asal bahasa), dan sebagainya.

\section{d. Struktur Kalimat (Sintaksis)}

Bahasa Arab memiliki struktur kalimat yang bervariasi seperti bahasabahasa yang lainnya. Antara lain untuk mengenal bunyi dan alat ucap melahirkan ilmu makharijul khuruf (fonetik) untuk mengenal perbedaan makna melahirkan ilmu funulujiyah (fonologi). Sedang untuk mengenal pembentukan kata melahirkan ilmu sharaf (morfologi), untuk mengenal strukturnya akan melahirkan ilmu nahwu (sintaksis), dan untuk memahami makna melahirkan ilmu ma'ani (semantik)

Struktur kalimat pada jenjang pendidikan tinggi meliputi;

\footnotetext{
${ }^{25}$ Ibid.
} 
1. Fa'il (dhahir dan dlamir baik muttashil maupun munfashil)

2. Maf'ul bih (dhahir dan dlamir)

3. Mubtada' (dhahir dan dlamir)

4. Khabar mubtada' baik berupa kata benda, kata sifat, maupun jar majrur.

5. Na'at man'ut

6. Idlafah lafdhiyah

Komponen pada poin-poin yang tersebut diatas, adalah terkait dengan aspek budaya yang terkandung dalam teks lisan dan tulisan.

\section{PENUTUP}

Beragamnya tuntutan masyarakat dan bervariasinya kebutuhan siswa di dalam proses pembelajaran ditambah lagi dengan kondisi geografi Indonesia yang sangat kompleks, seringkali tidak dapat diapresiasikan secara lengkap oleh birokrasi pusat. Oleh karena itu di dalam proses peningkatan mutu kurikulum perlu dicari alternatif pengelolaan aspek pendidikan yang satu ini. Hal ini mendorong lahirnya konsep manajemen peningkatan mutu kurikulum.

Manajemen alternatif ini memberikan kemandirian kepada peletak dasar, pengembang dan pelaksana kurikulum sekolah untuk mengatur dirinya sendiri dalam rangka peningkatan mutu pendidikan, tetapi masih tetap mengacu kepada kebijakan nasional. Konsekwensi dari pelaksanaan program ini adanya komitmen yang tinggi dari berbagai pihak yaitu orang tua/ masyarakat, guru, kepala sekolah, siswa dan staf lainnya di satu sisi dan pemerintah di sisi lainnya sebagai partner dalam mencapai tujuan peningkatan mutu kurikulum.

Dalam rangka pelaksanaan konsep manajemen ini, strategi yang dapat dilaksanakan oleh pemangku kebijakan antara lain meliputi evaluasi diri untuk menganalisa kekuatan dan kelemahan kurikulum. Berdasarkan hasil evaluasi tersebut sekolah bersama-sama orang tua dan masyarakat menentukan visi dan misi kurikulum dalam peningkatan mutu pendidikan atau merumuskan mutu yang diharapkan dan dilanjutkan dengan penyusunan rencana program sekolah termasuk pembiayaannya, dengan mengacu kepada skala prioritas dan kebijakan nasio-nal sesuai dengan kondisi sekolah dan sumber daya yang tersedia. Dalam penyusunan program, sekolah harus menetapkan indikator atau target mutu yang akan dicapai.

Kegiatan yang tak kalah pentingnya adalah melakukan monitoring dan evaluasi program yang telah direncanakan sesuai dengan pendanaannya untuk melihat ketercapaian visi, misi dan tujuan yang telah ditetapkan sesuai dengan kebijakan nasional dan target mutu yang dicapai serta melaporkan hasilnya kepada masyarakat dan pemerintah. Hasil evaluasi (proses dan output) ini selanjutnya dapat dipergunakan sebagai masukan untuk perencanaan/ penyusunan program pengembangan kurikulum di masa mendatang (tahun berikutnya). Demikian terus menerus sebagai proses yang berkelanjutan.

Untuk pengenalan dan menyamakan persepsi sekaligus untuk memperoleh masukan dalam rangka perbaikan konsep dan pelaksanaan manajemen ini, maka sosialisasi harus terus dilakukan. Kegiatankegiatan yang bersifat pilot/uji coba harus segera dilakukan untuk mengetahui kendala-kendala yang mungkin muncul di dalam pelaksanaannya untuk dicari solusinya dalam rangka mengantisipasi kemungkinan-kemungkian kendala yang muncul di masa mendatang. Harapannya dengan konsep ini, maka peningkatan mutu pendidikan lewat upaya perbaikan kurikulum khususnya dalam kerangka pembelajaran bahasa arab akan dapat diraih oleh kita sebagai pelaksanaan dari proses pengembangan sumber daya manusia menghadapi persaingan global yang semakin ketat dan ditunjang oleh ilmu pengetahuan dan teknologi yang berkembang secara cepat.

Pada poin kurikulum; berdasarkan kurikulum standar yang telah ditentukan 
secara nasional, sekolah bertanggung jawab untuk mengembangkan kurikulum baik dari standar materi (content) dan proses penyampaiannya. Melalui penjelasan bahwa materi tersebut ada mafaat dan relevansinya terhadap siswa, sekolah harus menciptakan suasana belajar yang menyenangkan dan melibatkan semua indera dan lapisan otak serta menciptakan tantangan agar siswa tumbuh dan berkembang secara intelektual dengan menguasai ilmu pengetahuan, terampil, memilliki sikap arif dan bijaksana, karakter dan memiliki kematangan emosional. Ada tiga hal yang harus diperhatikan dalam kegiatan ini yaitu;

1. pengembangan kurikulum tersebut harus memenuhi kebutuhan siswa.

2. bagaimana mengembangkan keterampilan pengelolaan untuk menyajikan kurikulum tersebut kepada siswa sedapat mungkin secara efektif dan efisien dengan memperhatikan sumber daya yang ada.

3. pengembangan berbagai pendekatan yang mampu mengatur perubahan sebagai fenomena alamiah di sekolah.

Untuk melihat progres pencapain kurikulum, siswa harus dinilai melalui proses test yang dibuat sesuai dengan standar nasional dan mencakup berbagai aspek kognitif, affektif dan psikomotor maupun aspek psikologi lainnya. Proses ini akan memberikan masukan ulang secara obyektif kepada orang tua mengenai anak mereka (siswa) dan kepada sekolah yang bersangkutan maupun sekolah lainnya mengenai performan sekolah sehubungan dengan proses peningkatan mutu pendidikan.

\section{DAFTAR PUSTAKA}

Dikmenum, 1999, Peningkatan Mutu Pendidikan Berbasis Sekolah: Suatu Konsepsi Otonomi Sekolah (paper kerja), Jakarta: Depdikbud.

Hamalik, Oemar. 2003. Kurikulum dan Pembelajaran. Jakarta: Bumi Aksara. 1990. Evaluasi Kurikulum, Bandung: Remaja Rosdakarya.

Hamid Hasan, S. 2008. Evaluasi Kurikulum, Bandung: Remaja Rosdakarya.

Hasibuan, Lias. 2010. Kurikulum \& Pemikiran Pendidikan, Jakarta : GP Press.

Halim, A. dkk. 2009. Manajemen Pesantren, Yogyakarta : Pustaka Pesantren.

Idi, Abdullah. 2009. Pengembangan Kurikulum Teori \& Praktek. Yogyakarta: Ar ruzz Media.

Listyo Prabowo, Sugeng. 2009. Implementasi Sistem Manajemen Mutu ISO 9001: 2008 di Perguruan Tinggi (Guidelines IWA -2). Malang : UIN Malang Press.

Ma'mur Asmani, Jamal. 2009. Manajemen Strategis Pendidikan Anak Usia Dini. Yogyakarta: DIVA Press.

Muhaimin, dkk. 2011. Manajemen Pendidikan: Aplikasinya dalam Penyusunan Rencana Pengembangan Sekolah/Madrasah. Jakarta: Kencana. ,2009. Rekonstruksi Pendidikan Islam dari Paradigma Pengembangan, Manajemen Kelembagaan, Kurikulum hingga Strategi Pembelajaran. Jakarta: PT Raja Grafindo Persada. 
.2008. Kurikulum Tingkat

Satuan Pendidikan, Jakarta:

Rajagrafindo Persada

Nasution, S. 2006. Asas asas Kurikulum.

Jakarta: Bumi Aksara.

Sudiyono, dkk. 2006. Strategi

Pembelajaran Partisipatori di

Perguruan Tinggi. Malang: UIN

Malang Press.

Saha Ghafur, A. Hanif. 2008. Manajemen Penjaminan Mutu Perguruan Tinggi di Indonesia. Jakarta: Bumi Aksara.

Sukmadinata, Nana Syaodith et al. 2006. Pengendalian Mutu Pendidikan Sekolah Menengah; Konsep, Prinsip, dan Instrumen. Bandung: Refika Aditama.

Uwes, Sanusi. 2003. Manajemen Pengembangan Mutu Dosen, Ciputat: Logos Wacana Ilmu.

Yamin, Moh. 2012. Panduan Manajemen Mutu Kurikulum Pendidikan, Yogyakarta: Diva Press. 